\section{The Implications of Information Technology Infrastructure for Key Performance Indicators of University Libraries - Results of the Preliminary Analysis}

\author{
Anita Kuźnik \\ MULF Library. Faculty of Management. \\ General Tadeusz Kościuszko Military University of Land Forces (MULF) \\ inWroctar,,Poland, anita.kuznik@arl.edu.pl \\ Maciej Popławski \\ Department of Economics and Quantitative Methods. Faculty of Management. \\ General Tadeusz Kościuszko Military University of Land Forces (MULF) \\ in Wroctarw, Poland, maciej.poplawski@arol.edu.pl \\ Stanisław Stanek \\ Department of IT Management Systems. Faculty of Management. \\ General Tadeusz Kościuszko Military University of Land Forces (MULF) \\ in Wroctarw, Poland, stanislaro.stanek@arwl.edu.pl
}

The Implications of Information Technology Infrastructure for Key Performance Indicators of University Libraries Results of the Preliminary Analysis

\begin{abstract}
The objective of the article is to determine the impact of information infrastructure on the functional indicators of university libraries. In the studies, the results of which were presented in the article, there was made a comparison between a group of 32 information infrastructure indicators with all functional indicators and the occurrence of convergence or divergence between them was examined. The aspects of library quality assessment were indicated and described, as well as the most important national and international standards regarding functional indicators. Next, the own research methodology was presented in details, comparative analysis and method of distance and pattern analysis were used as well as the results of the preliminary analysis carried out. In connection with the use of the original research method, the article provides a new perspective on research into the impact of information infrastructure on the functionality of university libraries. Preliminary studies have shown that technical and economics universities are better equipped with information infrastructure than those with a humanistic profile.
\end{abstract}

Keywords - information infrastructure, library functionalities, convergence, divergence

\section{Psynergía}

International Journal of Synergy and Research Vol. 6, 2017 pp. 77-89 
IJSR

6

\section{Introduction}

There is a great need to improve the management of information infrastructure in modern university academic libraries. In view of the overall increase in the importance of science in public life, information infrastructure is becoming increasingly important, which in the $21^{\text {st }}$ century is one of the most important resources held by universities. An organizational library that is particularly responsible for the management of information resources is the scientific library. Due to very formalized and, therefore, unpredictable nature of public HEIs, their scientific libraries, as compared to non-public HEIs, are slowly adapting to the changes in methods, concepts and modern solutions used in information management.

It is extremely important for the information technology to improve the functioning of the scientific library while minimizing the costs of using information technology (Grabowska, 2012). It is important to use large data, the so-called big data, in information management processes in university libraries. The information management sphere is constantly changing, strategies change, new problems and challenges emerge. The cause of change is the dynamic development of information and communication technologies, and, consequently, the global increase in data production. This forces librarians, info brokers and information management specialists to design new solutions for information gathering and processing (Wójcik, 2016). The term "big data" is used to denote large, disorderly and dynamically changing data sets. The specifics of large data are often described in $3 \mathrm{~V}$ or $4 \mathrm{~V}$ models. The Volume, Velocity, Variety $3 \mathrm{~V}$ model was developed in 2001 by Partner Analyst to show the main characteristics of big data - their size, diversity and variability. In newer interpretations, such as the $4 \mathrm{~V}$ model, there is another important feature added - Value, and Veracity, which is the credibility of raw data (Wójcik, 2016). The issue of using large data was a subject that was frequently and widely discussed in many fields, including: computer science, management, economics, marketing, medicine, banking or architecture. It is difficult to find works devoted to the use of large data in libraries and publications dealing with the consequences of big data for information management processes written from the perspective of bibliology and informatics. This is big data that is a huge potential for libraries. An example may be the project implemented by the British Library in consultation with University College London. The purpose of this project is to use Microsoft Azure software to streamline the flow of information in the humanities. The result is a platform to facilitate access to the distributed digital resources of the British Library. A similar initiative is being implemented by the Library of Congress. In this project big data processing is going to help in developing and sharing data from social networking sites (Wójcik, 2016).

The study presents the results of the analysis being part of a wider impact of information infrastructure on the functionality of university libraries research. It is assumed that the solutions for managing the information infrastructure in university libraries should be improved. Such attempts have already been made before, however, to a small extent. The authors examined the impact of the information infrastructure on a selected group of functional indicators.

The article consists of six chapters. In the first chapter, the choice of the topic of the study was justified, the purpose of the work and the concept of information infrastructure were discussed. The second chapter reviews literature on the analyzed topic, identifies 
and describes aspects of library quality assessment, and also presents the most important national and international standards regarding functional indicators. The next chapter presents the methodology of own research in detail. In the further part of the work, the results of the research were presented, which consisted of two stages. The fifth chapter is a discussion, and the final chapter presents the conclusions from the work. Due to the use of the original research method, the article provides a new perspective on the impact of information infrastructure on the functionality of university libraries research.

\section{Literature review}

The level of the functioning of the library infrastructure is being measured by a number of institutions worldwide, including the Webbmedia Group, which has published a compilation of modern methods for measuring the activity of academic libraries in Key Performance Indicator Toolkit. New Methods for Measuring a Library's Community Impact (2012). The paper by Abu Eid and Jirjees (2015) is also an interesting publication on the use of key indicators in the UAE. University libraries also conducted some studies, for example, the Leicester University Library made it on key performance indicators for key science libraries in the UK in 2016 (Key Performance Indicators 2016). Attempts to improve information infrastructure management solutions in the modern university library were also addressed, to a small extent, by Polish scientists. In this regard, Tomaszewski and Polarczyk (2017) presented one of the solutions which is the said learning library. In one of the articles entitled "The learning library" they presented the concept of learning organization (OUS), and discussed its essence and assumptions. In their work they attempted to answer the question whether libraries for higher education institutions would remain merely a theoretical model or a practical solution to today's problems. Orzechowski (2007), discusses the importance of information technologies in modern enterprises and organizations. These considerations can be transferred to universities. As already mentioned, modern libraries without IT cannot function. Wójcik (2016) highlighted the importance of using large data in information management processes in college libraries. As she noted, the processing of large data is a phenomenon that can significantly affect not only the way information is managed, but also the management of the information infrastructure of academic libraries. In the literature we can also find numerous works on the knowledge society. It is clear that modern libraries of higher education should actively contribute to the knowledge society. Chmielecka (2004) and Cisek (2017) rightly pointed out that access to information, more specifically, the ability to open up access to it, builds new social stratification.

The concept of information infrastructure has become popular with the widespread of the US, European Union, Organization for Economic Co-operation and Development (G-7), and G-7 programming documents devoted to various aspects of the ongoing civilizational changes related to the growing role of information society (Cisek, 2017). The impact of information technology on information infrastructure is undoubted. This is confirmed by numerous studies conducted by some authors, for example: Masrek and Jusoff (2009), who demonstrated this by exemplifying the intricacies of intranets, or Broadbent et al. (1999) who pointed to the key importance of IT for business process design.
The Implications of Information Technology Infrastructure for Key

Performance Indicators of University Libraries Results of the Preliminary Analysis 
IJSR

6

Information society is a society that utilizes a well-developed information and communication base in various spheres of social activity. Mass communication is important in the information society, as information is the backbone of this society, and the emergence of new means of communication extends the opportunities in this field. In the information society, information and the resulting knowledge and technology are the primary manufacturing factor, the labor force consists mostly of information workers, most of the gross national income is generated within the broadly understood information sector [1]. Apart from the undoubted advantages of the information society, there are also many shortcomings, which are broadly discussed by Lubacz (2017). He also points out the significant threat that institutional and regulatory issues will be the main obstacle to the development of a homogeneous, global information infrastructure (Lubacz, 2017).

Another important concept is the quality of service provided by the scientific library, which depends on the key performance indicators. The level of organization manifests itself in many dimensions, varying from one point of view. The library can be seen from the perspective of: users (current and potential), organizers and funding institutions, decision makers, library employees, library directors, and the public (Derfert-Wolf, 2017). Poll (2009) lists three aspects of library quality assessment:

- Functionality indicators: measure the efficiency and capability of library services; generate quantitative data and may be considered objective.

- User surveys: measure perception of quality; they generate qualitative data, but they are rather subjective.

- Evaluation of results: evaluates the value of the library and its benefits to individual users and society (Poll, 2009).

In the world and in Poland, we are increasingly aware of the high quality of library services and efforts to increase the effectiveness of library facilities. Management approaches include quality management approaches, including quality assurance (the library seeks to achieve ISO 9000 series certification) and TQM. It is, therefore, very important to develop and apply consistent, uniform and comparable performance indicators, i.e. measures (how to test and calculate) of the performance of libraries. Since 1998, ISO 11620: Information and Documentation - Library Performance Indicators, which defines these indices, is independent of the type of library (Derfert-Wolf, 2017).

In its latest edition of 2008, set up by the Polish Committee for Standardization in 2012, apart from the detailed description of the indicators, there are discussed the scope of the standard, the use of indicators, the rules of their selection for research and, the limits of application. It is emphasized that the main purpose of using library performance indicators is to self-assess the library, which may include comparing the library's performance over the years. The underlying goal may be the comparison between libraries. It should be borne in mind, however, that the quality and efficiency of library services as well as the efficiency of resource use (including financial resources) are assessed against its mission, objectives and tasks. This applies both to self-assessments as well as to comparative research. It is also important to note that the list of functional indicators in the standard is not a mandatory set, but a proposition of measurands that can be used in different conditions of the library's operations (Statystyka biblioteczna i..., 2017).

The current second edition of ISO 11620 combines performance indicators for both electronic and traditional library and resource services. The standard concerns 
the evaluation of libraries of all types, with the aim of increasing the use of indicators in libraries and disseminating knowledge about measurement methods. The basis for this edition is the above International Federation of Library Association and Institutes (IFLA) recommendations. The standard introduces standard terminology (47 defined terms, often referring to ISO 2789: 2006) and contains descriptions of 45 functional indicators selected according to the following criteria: information content, reliability, relevance, practicality, comparability (Statystyka biblioteczna i..., 2017).

Performance indicators are presented in ISO 11620 in accordance with the Balanced Scorecard concept, which assesses the functionality of a company in four areas: internal processes, customer, finance, and development. The solution was also implemented in libraries, used in national projects, e.g. German BIX, and the most common in IFLA recommendations.

\section{Research methodology}

The authors of the paper did the analysis of the impact of information infrastructure on key performance indicators of academic libraries. The analysis has been conducted in two stages using the indicators calculated in the AFBN, Question/Data from the Statistical Librarian Functional Analysis, National and International Standards: PN-ISO 11620: 2012documentation, Library functionalities, ISO 11620: 2014 Information and documentation, Library performance indicators and PN-ISO 2789: 2016 Information and documentation, International library statistics (Statystyka biblioteczna i..., 2017). The Research Project on the Functioning of Scientific Libraries in Poland by the Scientific Libraries Standards Team (ZSBN) has been running since 2001. Its main aim is to develop standards for libraries of Polish higher education [2].

In the AFBN project in 2015, from which data were used in the analysis, a total of 58 public university libraries participated, including:

- $\quad$ arts universities (2 out of 19),

- universities of economics (3 out of 5 people have applied),

- medical universities (10 out of 11 were registered),

- $\quad$ agricultural universities (1 out of 5 people has applied),

- universities with a technical profile, including maritime and military (21of 27 active),

- universities, including pedagogical academies (19 out of 25 were registered),

- physical education universities (2 out of 6 active) [2].

Studies in non-public schools also took part in the study (5 out of 289), however, due to their small share, they were not included in the analysis. Percentage of public and non-public libraries' research (compared to 63 ): non-public $-8 \%$ and public $-92 \%$ of all libraries surveyed [2].

Functional indicators (in total of 106) were divided into the following groups: general indicators (15) financial ratios (35), harvest indicators (20), usage indicators, e.g. loans, information services, training (23) concerning employees (13). A large number of indicators are due to the need to administer many of them to three categories of people:

1) user: number of full-time students + number of full-time and post-graduate students + number of university employees,
The Implications of Information Technology Infrastructure for Key Performance Indicators of University Libraries Results of the Preliminary Analysis 
IJSR

6

2) student: number of full-time students + number of full-time and post-graduate students + number of university employees,

3) student of full-time studies [2].

It is worth mentioning that the research carried out under the AFBN project may not be entirely reliable due to the fact that only some scientific libraries participated in the project.

In the first phase of analysis, based on data from the AFBN project, there was conducted a comparative analysis of the absolute values of selected indicators in 2015 in the different types of university libraries (Table 1), resulting in statistical conclusions about the functionalities of scientific libraries in 6 types of universities - universities, technical colleges, medical universities, economic universities, art colleges and physical education institutions.

The list of selected indicators used in Table 1 is as follows:

Name of the indicator

1. Expenditure of the library per user in PLN.

2. Expenditure on library collections per user in PLN.

3. Cost of using the harvest in PLN.

4. Library budget as percentage of college budget.

5. Registered users of their own university as a percentage of potential users.

6. Number of non-electronic library collections per user.

7. Number of printed books purchased per user.

8. Expenditure on printed Polish and foreign books as a percentage of expenditure on library collections.

9. Expenditure on electronic resources as a percentage of expenditure on library collections.

10. The ratio of expenditure on collection and handling of collections to staff costs.

11. Number of users per library employee.

12. Library area per user.

13. Number of users per place to work in the library.

14. Users actively borrow as a percentage of registered users.

15. Number of loans per registered user.

16. Number of loans per active user.

17. Visits in the library per user.

18. Active use of non-electronic collections (turnover).

19. Number of downloaded documents from licensed electronic journals and full-text databases per user.

20. Number of times a publication is published from its own digital library per user.

21. Completed interlibrary loan orders as a percentage of the orders placed.

22. Number of hours of training and instruction for users per library employee.

23. Employees with librarianship as a percentage of basic workforce.

24. Number of library staff publications per employee of core activity.

25. Number of hours of professional training per library employee.

26. Increase of collections (books).

27. Number of users per computer station with Internet access.

28. Number of books printed in free access as a percentage of the total number of books in collections. 
29. Number of documents digitized per year per 1,000 titles of the entire library collection.

30. Time to adopt a book.

31. Number of hours (week) in which library services are available.

In the second stage of the analysis, the next table containing 106 indicators of the functionalities of public higher education (median) libraries in different types of libraries was constructed, depending on the type of institution. Subsequently, the data in Table 2 were transferred to Table 3 where the absolute values were converted at their distance from the standard set as the mean of all types of public HEIs for the individual indicators, assuming a median mean of 100 (see Table 3). At the same time, out of all the indicators included in Table 3, 32 indicators of information infrastructure were singled out and separated from other functional indicators. A separate set of indicators was compared against all functional indicators by examining the occurrence of convergence or divergence between them, so that it was possible to determine the impact or lack of influence of the information infrastructure on the key performance indicators of the analyzed types of academic libraries.

\section{Research findings/results}

\subsection{Research results of the first stage of the analysis}

As a result of the implementation of the first stage of the analysis of selected functional indicators (medians), economic universities have as many as 10 highest values of the median, in terms of the lowest values, there are only 3 . In the list of the lowest ranked universities of physical education, they have only two highest median values, and as few as 11 median values (see Table 1).

As for the universities of economics, the highest-performing values can be found in: library budget as a percentage of college budget, number of printed books per user, number of user fees per user, library visit per user, non-electronic resource usage (turnover), number of downloaded documents from licensed electronic journals and full-text databases per user, completed interlibrary loan orders as a percentage of placed orders, number of hours of participation in vocational training per library employee, number of books printed in free access as a percentage of the total number of books in collections, number of hours (week) in which library services are available. The highest ratios are included in the use of such services as borrowing, information services, training. In turn, the lowest values were for the following indicators: the cost of harvesting, the number of library staff publications per employee of the core activity, and the increase of the collections (books). These lowest values relate to indicators from the financial, employee and collections groups.

In the case of physical education universities, the lowest values appeared in the following ratios: user-generated library expenditures, the number of non-electronic library collections per user, the number of purchased printed books per user, the ratio of expenditure on collection and handling of collections to staff costs, number of downloads from licensed electronic journals and full-text databases per user, number
The Implications of Information Technology Infrastructure for Key Performance Indicators of University Libraries Results of the Preliminary Analysis 
Pobrane z czasopisma International Journal of Synergy and Research http://ijsr.journals.umcs.pl

Data: 26/04/2023 17:22:09

84

\section{IJSR}

6

Table 1.

Comparison of selected indicators for 2015 in different types of public university libraries (absolute values)

\begin{tabular}{|c|c|c|c|c|c|c|c|}
\hline $\begin{array}{l}\text { Selected } \\
\text { functional } \\
\text { indicators } \\
\text { (medians) }\end{array}$ & $\begin{array}{c}\text { Universities } \\
\text { (19) }\end{array}$ & \begin{tabular}{|c|} 
Technical \\
universities \\
(21)
\end{tabular} & $\begin{array}{c}\text { Medical } \\
\text { universities } \\
\text { (10) }\end{array}$ & $\begin{array}{c}\text { Universities } \\
\text { of } \\
\text { economics } \\
\text { (3) }\end{array}$ & $\begin{array}{c}\text { Arts } \\
\text { universities } \\
\text { (2) }\end{array}$ & $\begin{array}{l}\text { Physical } \\
\text { education } \\
\text { universities } \\
\text { (2) }\end{array}$ & Average \\
\hline 1 & 384.8 & 272.6 & 442.6 & 364.4 & 887.3 & 288.2 & 440.0 \\
\hline 2 & 42.2 & 44.6 & 113.5 & 57.2 & 65.9 & 25.1 & 58.1 \\
\hline 3 & 9.5 & 11.2 & 13.3 & 4.8 & 49.2 & 18.7 & 17.8 \\
\hline 4 & 2.70 & 1.97 & 1.61 & 4.00 & 2.44 & 1.84 & 2.43 \\
\hline 5 & 68.9 & 80.4 & 64.6 & 79.1 & 97 & 68.1 & 76.3 \\
\hline 6 & 59 & 26 & 33 & 28 & 144 & 25 & 52.5 \\
\hline 7 & 0.23 & 0.18 & 0.18 & 0.35 & 0.26 & 0.13 & 0.22 \\
\hline 8 & 34.27 & 28.85 & 20.61 & 20.92 & 15.53 & 24.89 & 24.18 \\
\hline 9 & 32.59 & 46.04 & 60.28 & 45.28 & 17.28 & 49.23 & 41.78 \\
\hline 10 & 0.2 & 0.2 & 0.4 & 0.2 & 0.1 & 0.1 & 0.2 \\
\hline 11 & 250 & 386 & 279 & 333 & 107 & 291 & 274 \\
\hline 12 & 0.56 & 0.21 & 0.26 & 0.32 & 0.67 & 0.21 & 0.37 \\
\hline 13 & 47 & 57 & 50 & 53 & 29 & 56 & 49 \\
\hline 14 & 66 & 60 & 66 & 82 & 77 & 89 & 73 \\
\hline 15 & 8.2 & 5.4 & 5.8 & 9.4 & 6.7 & 6.3 & 7.0 \\
\hline 16 & 12.1 & 8.7 & 9.1 & 9.4 & 9.5 & 7.0 & 9.3 \\
\hline 17 & 8.0 & 5.2 & 3.9 & 10 & 7.8 & 6.4 & 6.9 \\
\hline 18 & 0.3 & 0.4 & 0.3 & 0.9 & 0.1 & 0.6 & 0.4 \\
\hline 19 & 8.6 & 9.1 & 20.7 & 40.3 & 4.6 & 2.5 & 14.3 \\
\hline 20 & 13.45 & 9.1 & 12.45 & 12.6 & 6.61 & 1.13 & 9.22 \\
\hline 21 & 89.3 & 95.9 & 90.5 & 96.9 & 83.8 & 88.3 & 90.8 \\
\hline 22 & 4.8 & 3.6 & 10.8 & 8.9 & 1.6 & 0.7 & 5.1 \\
\hline 23 & 67.5 & 74 & 67.1 & 69.2 & 87.3 & 68.4 & 72.2 \\
\hline 24 & 0.2 & 0.2 & 0.2 & 0.0 & 0.2 & 0.1 & 0.1 \\
\hline 25 & 5 & 14 & 12 & 17 & 9 & 13 & 12 \\
\hline 26 & 10932 & 1720 & 197 & 90 & 429 & 144 & 2252 \\
\hline 27 & 435 & 192 & 211 & 319 & 84 & 650 & 315 \\
\hline 28 & 13 & 20 & 5 & 30 & 14 & 3 & 14 \\
\hline 29 & 0.05 & 0.06 & 0.02 & 0.03 & 0.05 & 0.00 & 0.03 \\
\hline 30 & 10 & 6 & 6 & 5 & 3 & 9 & 6 \\
\hline 31 & 62 & 60 & 66 & 67 & 44 & 51 & 58 \\
\hline
\end{tabular}

Source: Own elaboration based on: http://pliki.sbp.pl/afb/afbn/AFBN-wszystkie-publiczne-2015.pdf [access: 13.09.2017]. 
of views of digital library publications per user, number of hours of training and instruction for users per library employee, the number of books printed in free access as a percentage of the total number of books in collections, and the number of digitalized documents in a year, converted into 1,000 titles of the entire library collection. These lowest values relate to indicators from the financial, general, harvest and service sectors, e.g. borrowing, information services, training. As for the highest values of physical education institutions, only two indicators can be mentioned: users actively borrow as a percentage of registered users and number of users per computer station with access to the Internet. These are indicators from general and service usage, such as borrowing, information services, training.

\subsection{Research results of the second stage of the analysis}

Subsequently, the data of Table 1 were transferred to Table 2 where the absolute values were converted at their distance from the standard set as the mean of all types of public HEIs for the individual indicators, assuming a median mean of 100 (see Table 2). At the same time, out of all the indicators included in Table 2, 32 indicators of information infrastructure were separated and separated from other functional indicators.

A separate set of indicators was compared against all functional indicators by examining the occurrence of convergence or divergence between them, so that it was possible to determine the impact or lack of influence of the information infrastructure on the key performance indicators of the analyzed types of academic libraries. A chart below illustrates the convergence or divergence of both surveyed categories of indicators showing the impact (or lack of it) of the information infrastructure on the key performance indicators of the analyzed types of academic libraries (Figure 1).

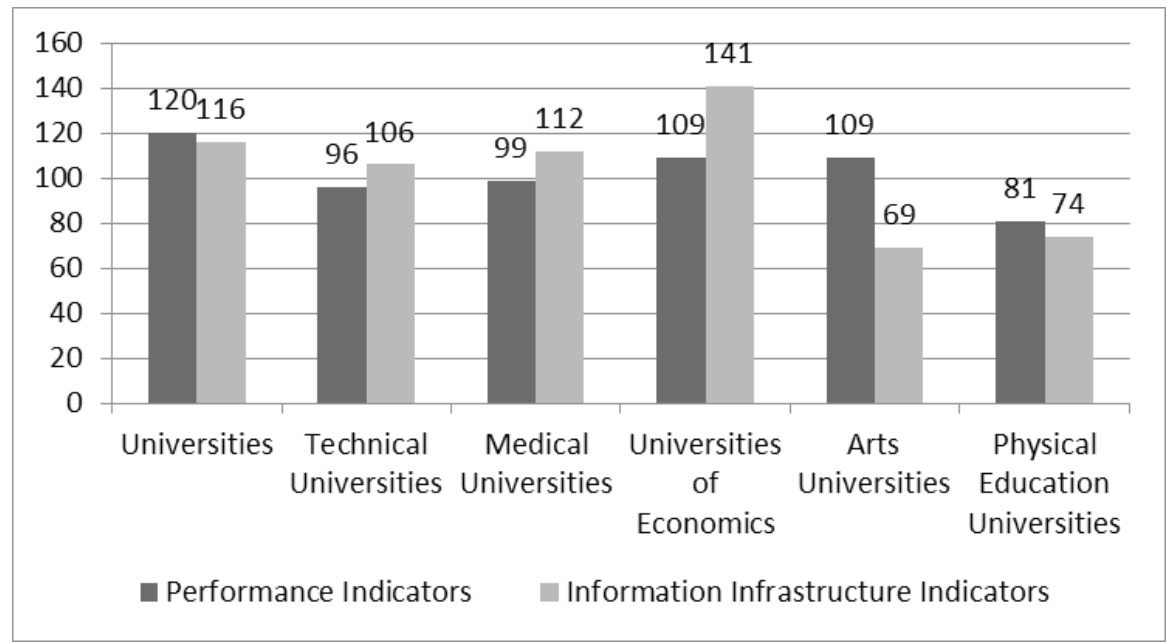

Source: Own elaboration.
The Implications of Information Technology Infrastructure for Key Performance Indicators of University Libraries Results of the Preliminary Analysis

Fiĝure 1.

Convergence and divergence of overall performance indicators of public university libraries and indicators of information infrastructures of public university libraries in 2015 
Pobrane z czasopisma International Journal of Synergy and Research http://ijsr.journals.umcs.pl

Data: 26/04/2023 17:22:09

86

\section{IJSR}

6

Table 2.

Distances of functional indicators of public library (median) depending on the type of institution, the standard set as the mean of all types of academic libraries public universities for individual indicators (average $=100$ ) (sample values)

\begin{tabular}{|c|c|c|c|c|c|c|c|}
\hline $\begin{array}{l}\text { Selected } \\
\text { functional } \\
\text { indicators } \\
\text { (medians) }\end{array}$ & $\begin{array}{c}\text { Universities } \\
\text { (19) }\end{array}$ & $\begin{array}{c}\text { Technical } \\
\text { universities } \\
\text { (21) }\end{array}$ & $\begin{array}{c}\text { Madical } \\
\text { universities } \\
\text { (10) }\end{array}$ & $\begin{array}{c}\text { Universities } \\
\text { of } \\
\text { economics } \\
\text { (3) }\end{array}$ & $\begin{array}{c}\text { Arts } \\
\text { universities } \\
\text { (2) }\end{array}$ & $\begin{array}{l}\text { Physical } \\
\text { education } \\
\text { universities } \\
\text { (2) }\end{array}$ & Average \\
\hline 1 & 87 & 62 & 101 & 83 & 202 & 66 & 100 \\
\hline 2 & 73 & 77 & 195 & 98 & 113 & 43 & 100 \\
\hline 3 & 53 & 63 & 75 & 27 & 276 & 105 & 100 \\
\hline 4 & 111 & 81 & 66 & 165 & 100 & 76 & 100 \\
\hline 5 & 90 & 105 & 85 & 104 & 127 & 89 & 100 \\
\hline 6 & 112 & 50 & 63 & 53 & 274 & 48 & 100 \\
\hline 7 & 105 & 82 & 82 & 159 & 118 & 59 & 100 \\
\hline 8 & 142 & 119 & 85 & 87 & 64 & 103 & 100 \\
\hline 9 & 78 & 110 & 144 & 108 & 41 & 118 & 100 \\
\hline 10 & 100 & 100 & 200 & 100 & 50 & 50 & 100 \\
\hline 11 & 91 & 141 & 102 & 122 & 39 & 106 & 100 \\
\hline 12 & 151 & 57 & 70 & 86 & 181 & 57 & 100 \\
\hline 13 & 96 & 116 & 102 & 108 & 59 & 114 & 100 \\
\hline 14 & 90 & 82 & 90 & 112 & 105 & 122 & 100 \\
\hline 15 & 117 & 77 & 83 & 134 & 96 & 90 & 100 \\
\hline 16 & 130 & 94 & 98 & 101 & 102 & 75 & 100 \\
\hline 17 & 116 & 75 & 57 & 145 & 113 & 93 & 100 \\
\hline 18 & 75 & 100 & 75 & 225 & 25 & 150 & 100 \\
\hline 19 & 60 & 64 & 145 & 282 & 32 & 17 & 100 \\
\hline 20 & 146 & 99 & 135 & 137 & 72 & 12 & 100 \\
\hline 21 & 98 & 106 & 100 & 107 & 92 & 97 & 100 \\
\hline 22 & 94 & 71 & 212 & 175 & 31 & 14 & 100 \\
\hline 23 & 93 & 102 & 93 & 96 & 121 & 95 & 100 \\
\hline 24 & 200 & 200 & 200 & 0 & 200 & 100 & 100 \\
\hline 25 & 42 & 117 & 100 & 142 & 75 & 108 & 100 \\
\hline 26 & 485 & 76 & 9 & 4 & 19 & 6 & 100 \\
\hline 27 & 138 & 61 & 67 & 101 & 27 & 206 & 100 \\
\hline 28 & 93 & 143 & 36 & 214 & 100 & 21 & 100 \\
\hline 29 & 167 & 200 & 67 & 100 & 167 & 0 & 100 \\
\hline 30 & 167 & 100 & 100 & 83 & 50 & 150 & 100 \\
\hline 31 & 107 & 103 & 114 & 116 & 76 & 88 & 100 \\
\hline
\end{tabular}

Source: Own elaboration based on: http://pliki.sbp.pl/afb/afbn/AFBN-wszystkie-publiczne-2015.pdf [access: 13.09.2017]. 
Pobrane z czasopisma International Journal of Synergy and Research http://ijsr.journals.umcs.pl

Data: 26/04/2023 17:22:09

\begin{tabular}{|c|c|c|c|c|c|c|c|c|c|c|c|c|c|}
\hline 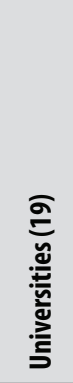 & 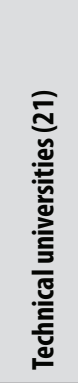 & 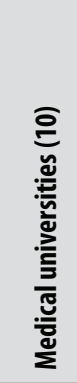 & 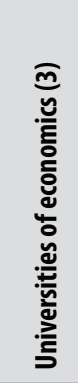 & 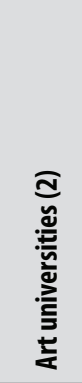 & 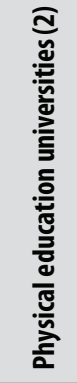 & $\begin{array}{l}\text { 등 } \\
\text { 总 }\end{array}$ & 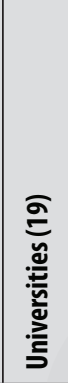 & 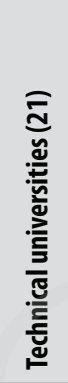 & 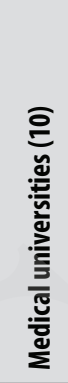 & 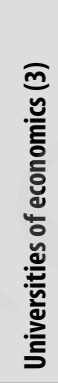 & 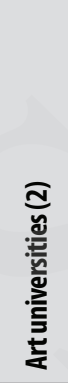 & 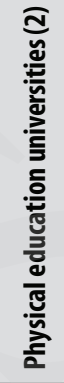 & 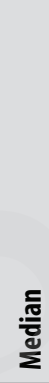 \\
\hline 32.59 & 46.04 & 60.28 & 45.28 & 17.28 & 49.23 & 41.78 & 78 & 110 & 144 & 108 & 41 & 118 & 100 \\
\hline 0.2 & 0.2 & 0.4 & 0.2 & 0.1 & 0.1 & 0.2 & 100 & 100 & 200 & 100 & 50 & 50 & 100 \\
\hline 250 & 386 & 279 & 333 & 107 & 291 & 274 & 91 & 141 & 102 & 122 & 39 & 106 & 100 \\
\hline 0.56 & 0.21 & 0.26 & 0.32 & 0.67 & 0.21 & 0.37 & 151 & 57 & 70 & 86 & 181 & 57 & 100 \\
\hline 47 & 57 & 50 & 53 & 29 & 56 & 49 & 96 & 116 & 102 & 108 & 59 & 114 & 100 \\
\hline 66 & 60 & 66 & 82 & 77 & 89 & 73 & 90 & 82 & 90 & 112 & 105 & 122 & 100 \\
\hline 8.2 & 5.4 & 5.8 & 9.4 & 6.7 & 6.3 & 7 & 117 & 77 & 83 & 134 & 96 & 90 & 100 \\
\hline 12.1 & 8.7 & 9.1 & 9.4 & 9.5 & 7 & 9.3 & 130 & 94 & 98 & 101 & 102 & 75 & 100 \\
\hline 8 & 5.2 & 3.9 & 10 & 7.8 & 6.4 & 6.9 & 116 & 75 & 57 & 145 & 113 & 93 & 100 \\
\hline 0.3 & 0.4 & 0.3 & 0.9 & 0.1 & 0.6 & 0.4 & 75 & 100 & 75 & 225 & 25 & 150 & 100 \\
\hline 8.6 & 9.1 & 20.7 & 40.3 & 4.6 & 2.5 & 14.3 & 60 & 64 & 145 & 282 & 32 & 17 & 100 \\
\hline 13.45 & 9.1 & 12.45 & 12.6 & 6.61 & 1.13 & 9.22 & 146 & 99 & 135 & 137 & 72 & 12 & 100 \\
\hline 89.3 & 95.9 & 90.5 & 96.9 & 83.8 & 88.3 & 90.8 & 98 & 106 & 100 & 107 & 92 & 97 & 100 \\
\hline 4.8 & 3.6 & 10.8 & 8.9 & 1.6 & 0.7 & 5.1 & 94 & 71 & 212 & 175 & 31 & 14 & 100 \\
\hline 67.5 & 74 & 67.1 & 69.2 & 87.3 & 68.4 & 72.2 & 93 & 102 & 93 & 96 & 121 & 95 & 100 \\
\hline 0.2 & 0.2 & 0.2 & 0 & 0.2 & 0.1 & 0.1 & 200 & 200 & 200 & 0 & 200 & 100 & 100 \\
\hline 5 & 14 & 12 & 17 & 9 & 13 & 12 & 42 & 117 & 100 & 142 & 75 & 108 & 100 \\
\hline 10932 & 1720 & 197 & 90 & 429 & 144 & 2252 & 485 & 76 & 9 & 4 & 19 & 6 & 100 \\
\hline 435 & 192 & 211 & 319 & 84 & 650 & 315 & 138 & 61 & 67 & 101 & 27 & 206 & 100 \\
\hline 13 & 20 & 5 & 30 & 14 & 3 & 14 & 93 & 143 & 36 & 214 & 100 & 21 & 100 \\
\hline 0.05 & 0.06 & 0.02 & 0.03 & 0.05 & 0 & 0.03 & 167 & 200 & 67 & 100 & 167 & 0 & 100 \\
\hline 10 & 6 & 6 & 5 & 3 & 9 & 6 & 167 & 100 & 100 & 83 & 50 & 150 & 100 \\
\hline 62 & 60 & 66 & 67 & 44 & 51 & 58 & 107 & 103 & 114 & 116 & 76 & 88 & 100 \\
\hline
\end{tabular}

The Implications of Information Technology Infrastructure for Key

Performance Indicators of University Libraries Results of the Preliminary Analysis

Table 3. Distances of functional indicators of university libraries of public universities (median) depending on the type of university from the standard established as the average of all types of scientific libraries public universities for individual indicators (average $=100)$ (example values)

Source: Own elaboration based on http://pliki.sbp.pl/afb/afbn/AFBN-wszystkie-publiczne-2015.pdf [access: 13.09.2017]. 
IJSR

6

\section{Discussion}

As a result of the analysis carried out in the second stage it was shown that in the case of university libraries, art schools and physical education schools there is a convergence between total library functional indicators and libraries' information infrastructure indicators, which means that the impact of information infrastructure on their functioning is significant. It should be noted that the greatest impact of information infrastructure was on art schools. As far as technical, medical and economic universities are concerned, there is a divergence between total library functional indicators and library information infrastructure indicators, which means that the impact of information infrastructure on their functioning is less significant. The biggest discrepancies can be observed at economic universities. However, in each of the analyzed cases, a difference of no more than 32 and no less than $4 \%$ can be observed.

\section{Conclusions}

The results of the research proved to be a big surprise as the technical and economic universities seem to be better equipped with information infrastructure than the humanities. So the question arises: do the scientific libraries of Polish public high schools with strict profiles not manage the information infrastructure properly, or are the academic libraries of the humanities academies doing better? And how do these conclusions relate to the results of research conducted in academic libraries of foreign universities? These questions open the field for further research and discussion, especially in the context of the development of management methods as far as this important resource in modern scientific libraries is concerned, and in the context of Polish universities' aspirations to be ranked among the best.

\section{References}

Abu Eid, M.E., Jirjeesa, M.J. (2015). Application of Key Performance Indicators (KPIs) in the UAE Public Libraries. An Analytical Study. Qscience Proceedings, Bloomsbury Qatar Foundation Journals, Abu Dhabi.

Broadbent, M., Weill, P., St. Clair, D. (1999). The Implications of Information Technology Infrastructure for Business Process Redesign. MIS Quarterly, vol. 23, no. 2, pp. 159-182.

Cisek, S. (2017). Funkcje i role bibliotek naukowych i publicznych $w$ społeczeństwie wiedzy. Retrieved October 15, 2017 from: http://www.cbr.edu.pl/konf2005mat/ondex_konf.html

Chmielecka, E. (2004). Informacja, wiedza, mądrość. Co społeczeństwo wiedzy cenić powinno? Nauka i Szkolnictwo Wyższe, nr 1, pp. 12-13.

Derfert-Wolf, L. (2017). Wskaźniki funkcjonalności i statystyka biblioteczna - normy międzynarodowe, krajowe i sprawozdawczość GUS. Retrieved October 15, 2017 from: http://eprints.rclis.org/19654/1/Derfert_Lodz\%202012.pdf

Grabowska, H. (2012). Biblioteka ucząca się - zmiany w organizacji i systemie zarządzania w Bibliotece Uniwersytetu Finlandii Wschodniej. Biblioteka, nr 16, pp. 284-286.

Key Performance Indicators 2016, University of Leicester, Leicester. Retrieved July 22, 2017 from: www.le.ac.uk/library

Key Performance Indicator Toolkit. New Methods For Measuring a Library's Community Impact, by Webbmedia Group, Feb. 2012, Chicago. 
Lubacz, J. (2017). Infrastruktura informacyjna - opcje i dylematy rozwoju. Retrieved October 15, 2017 from: http://kbn.icm,pl/pub/info/iriss/konferxi.html

Masrek M.N., Jusoff, K. (2009).The Effect of Information Technology Infrastructure Flexibility on Intranet Effectiveness. Computer and Information Science, vol. 2, no. 2. Retrieved October 15, 2017 from: www.ccsenet.org/journal.html

Orzechowski, R. (2007). Efektywne zastosowanie IT w przedsiębiorstwie. E-mentor, no. 3(20).

Poll, R. (2009). Benchmarking in the form of performance indicators and Balanced Scorecard. In: M. Heaney, K.G. Saur (eds.), Library Statistics for the Twenty-First Century World, proceedings of the conference held in Montréal on 18-19 August 2008 reporting on the Global Library Statistics Project, München, pp. 61-71.

Statystyka biblioteczna i badania efektywności bibliotek. Projekty krajowe, międzynarodowe $i$ dokumenty normalizacyjne. Retrieved August 12, 2017 from: http://pliki.sbp.pl/afb/ statystyka-i-badania-efektywnosci-bibliotek.pdf

Tomaszewski, R., Polarczyk, M. (2017). Biblioteka ucząca się. II Konferencja Biblioteki Politechniki Łódzkiej. Biblioteki XXI wieku. Czy przetrwamy? Retrieved October 15, 2017 from: http://www.ebib.pl/publikacje/matkonf/biblio21/sesja3ref2.pdf

Wójcik, M. (2016). Big data w zarządzaniu informacją - przegląd wybranych zagadnień. In: S. Cisek (Ed.), Inspiracje i innowacje: zarzadzanie informacja $w$ perspektywie bibliologii i informatologii, Biblioteka Jagiellońska, Kraków, pp. 61-68.

[1] https://www.erainformatyki.pl/spoleczenstwo-informacyjne-definicja-cechy-zalety-wady.html [access: 01.08.2017].

[2] http://afb.sbp.pl/afbn/ [access: 28.08.2017].
The Implications

of Information

Technology

Infrastructure for Key

Performance

Indicators

of University

Libraries -

Results of

the Preliminary Analysis 
